\title{
PERBANDINGAN NILAI KEKERASAN PERMUKAAN ENAMEL PADA PERENDAMAN OBAT KUMUR CENGKEH DENGAN DAN TANPA PENAMBAHAN SALIVA BUATAN
}

\author{
Yumi Lindawati*, Novia** \\ *Departemen Biologi Oral Fakultas Kedokteran Gigi \\ **Mahasiswa Fakultas Kedokteran Gigi \\ Universitas Sumatera Utara \\ Jl. Alumni No.2 Kampus USU Medan \\ Telp. 0618216131 Fax. 0618213421
}

\begin{abstract}
Nowadays herbal mouthwash is widely consumed by the society, one of which is mouthwash containing cloves. Cloves contain minerals such as calcium and phosphorus which can help the remineralization of enamel. Mouthwash containing clove oil has antibacterial, antimicrobial effects, and can inhibit decalcification of enamel. The purpose of this study was to investigate the effect of immersion in clove mouthwash and the effect of of immersion in clove mouthwash with addition of artificial saliva on the hardness of enamel surface after immersion in commercial orange juice. It was a laboratory experimental pre-posttest control group design. Thirty two permanent maxillary first premolar extracted for orthodontic reason which qualify inclusion and exclusion criteria were used in this study. All samples were immersed in commercial orange juice for 5 minutes for demineralization then they were divided into group of clove mouthwash immersion without addition of artificial saliva and group of clove mouthwash immersion with addition of artificial. The surface enamel hardness before immersion, after immersed in commercial orange juice and after immersed in clove mouthwash of each sample was measured using Microvickers Hardness Tester FM-800. The results of the research that has been tested with Paired T-Test showed a significant decrease $(p<0,05)$ of surface enamel hardness in clove mouthwash immersion without addition of artificial saliva group, while the group of clove mouthwash immersion with addition of artificial saliva showed a significant increase $(p<0,05)$ of surface enamel hardness. The conclusion of this research showed that the value of enamel hardness is higher with the addition of artificial saliva than without addition of artificial saliva in clove mouthwash.
\end{abstract}

Keywords : enamel, clove mouthwash, saliva, hardness of enamel

\section{PENDAHULUAN}

Penggunaan berbagai macam obat kumur mulai dikenal luas dikalangan masyarakat. Obat kumur bermanfaat untuk menghilangkan bau mulut juga menghambat dan mengurangi pembentukan plak bakteri. Di antara berbagai produk obat kumur yang beredar luas di masyarakat, banyak yang berbahan dasar kimia, namun pada penggunaan jangka panjang didapati efek samping seperti warna coklat pada gigi, rasa yang kurang enak, ulserasi mukosa mulut dan parestesi. ${ }^{1}$ Oleh karena itu saat ini banyak masyarakat lebih memilih produk yang berasal dari bahan alami, salah satunya adalah obat kumur yang mengandung cengkeh. ${ }^{2}$

Cengkeh (Syzygium Aromaticum) adalah tanaman asli Indonesia dan sampai saat ini, sebagian besar kebutuhan cengkeh dunia (80\%) masih dipasok oleh Indonesia, disusul oleh Madagaskar dan Tanzania. ${ }^{3}$ Cengkeh memiliki efek antivirus, antiseptik, analgesik dan antifungal alami sehingga banyak dimanfaatkan dalam bidang kesehatan, seperti mengobati radang lambung, perut kembung, hipertensi, sakit kepala, sakit telinga, sakit gigi, batuk, dan bau mulut. Bagian dari cengkeh yang banyak dimanfaatkan adalah bunganya, karena memiliki kandungan minyak terbanyak. Kandungan mineral dalam cengkeh diantaranya adalah tembaga (27\%), zat besi (16\%), magnesium (15\%), mangan $(11 \%)$, zinc $(<0,5 \%)$, kalsium $(4 \%)$, dan fosfor $(13 \%){ }^{2}$ Kandungan kalsium dan fosfor merupakan mineral penting dalam proses remineralisasi enamel. ${ }^{4}$

Al-lami AHK dan Al-lousi WS di Irak (2011) menunjukkan bahwa larutan ekstrak bunga cengkeh $1 \%$, $5 \%$, dan $10 \%$ dapat meningkatkan kekerasan enamel pada gigi yang terdemineralisasi secara signifikan, peningkatan kekerasan tertinggi adalah pada konsentrasi 5\%. Peningkatan kekerasan enamel dipengaruhi oleh kandungan kalsium dan fosfor pada cengkeh yang merupakan komponen mayor dari kristal hidroksiapatit enamel. ${ }^{5}$ Marya CM dkk di India (2012) menunjukkan 
bahwa minyak cengkeh $0,05 \%$ dapat menghambat proses dekalsifikasi enamel oleh jus apel. Kandungan eugenol dan eugenil asetat yang terdapat dalam minyak cengkeh dipercaya dapat menghambat dekalsifikasi enamel meskipun diperlukan penelitian lebih lanjut. ${ }^{6}$

Penjualan minuman ringan, termasuk diantaranya jus jeruk kemasan meningkat sebanyak $56 \%$ selama 10 tahun terakhir dan diperkirakan akan terus meningkat sebanyak $2-3 \%$ per tahun. $^{7}$ Penelitian in vitro yang dilakukan oleh Machado C dkk di Amerika Serikat (2008) menunjukkan bahwa kekerasan enamel pada manusia secara signifikan menurun setelah kontak dengan minuman jus jeruk. ${ }^{8}$

Remineralisasi adalah proses dimana ion kalsium dan fosfat kembali masuk kedalam kristal hidroksiapatit. Kunci utama dalam proses remineralisasi adalah dengan mengembalikan $\mathrm{pH}$ rongga mulut ke tingkat yang lebih tinggi daripada $\mathrm{pH}$ kritis enamel dan terdapat ion kalsium dan fosfat yang cukup pada rongga mulut. Saliva mengandung ion kalsium dan fosfat yang dapat menghambat proses penguraian hidroksiapati. Hal ini memungkinkan pembentukan kembali kristal apatit yang telah terpisah. Selain itu, saliva juga berfungsi sebagai buffer yang dapat menetralkan asam.,

Penelitian ini bertujuan untuk mengetahui pengaruh perendaman obat kumur cengkeh dan pengaruh perendaman obat kumur cengkeh yang ditambah saliva buatan terhadap kekerasan permukaan enamel gigi yang telah direndam dalam jus jeruk kemasan.

\section{BAHAN DAN METODE}

Penelitian ini merupakan penelitian eksperimental laboratoris pre-posttest control group design yang dilakukan di Laboratorium Mikrobiologi FMIPA USU dan Laboratorium Teknik Mesin UNIMED. Kriteria inklusi adalah gigi premolar satu atas yang telah diekstraksi, bebas karies, dan tidak ada tambalan. Kriteria eksklusi adalah gigi yang karies, mengalami erosi, atrisi, abrasi, terdapat tambalan, terdapat fraktur, dan nekrosis. Jumlah sampel terdiri dari 32 gigi premolar satu atas yang telah diekstraksi dan memenuhi kriteria inklusi dan eksklusi.

Sampel gigi dipotong pada batas cementoenamel junction hingga menyisakan bagian mahkota. Permukaan mahkota gigi yang akan tertanam dalam resin dilapisi dengan nail varnish pada bagian cementoenamel junction ke arah palatal, sedangkan pada bagian cementoenamel junction ke arah bukal dilapisi dengan wax. Bagian mahkota gigi yang tidak tertutupi wax lalu ditanam dalam self-curing resin hingga gigi stabil pada basis resin, lalu permukaan bukal sampel diratakan dengan kertas pasir dengan ketentuan enamel yang terbuang tidak sampai $100 \mu \mathrm{m}$ lalu sampel dibersihkan dengan aquabidest, kemudian diukur kekerasan awal permukaan enamel.

Seluruh sampel direndam dalam jus jeruk kemasan selama 5 menit untuk demineralisasi kemudian diacak dan dibagi menjadi 8 kelompok perendaman, dimana setiap kelompok terdiri dari 4 sampel (A1 sampai A4 direndam dalam obat kumur cengkeh, B1 sampai B4 direndam dalam obat kumur cengkeh yang ditambah saliva buatan) dengan waktu perendaman berbeda $(\mathrm{A} 1, \mathrm{~B} 1=30$ detik, $\mathrm{A} 2, \mathrm{~B} 2=1$ menit, $\mathrm{A} 3, \mathrm{~B} 3=2$ menit, $\mathrm{A} 4, \mathrm{~B} 4=4$ menit) lalu direndam dalam aquabidest selama 24 jam didalam inkubator $37^{\circ} \mathrm{C}$. Penelitian dilakukan selama 1 minggu.

Setiap sampel dilakukan pengukuran kekerasan permukaan enamel awal, setelah perendaman jus jeruk kemasan dan obat kumur cengkeh menggunakan alat uji kekerasan Microvickers Hardness Tester FM-800. Setiap sampel dilakukan pengukuran kekerasan sebanyak 3 kali lalu diambil rata-ratanya yang merupakan kekerasan permukaan sampel.

Sebelum penelitian ini dimulai, peneliti sudah mendapatkan persetujuan dari Komite Etik Penelitian Bidang Kesehatan Fakultas Kedokteran Universitas Sumatera Utara, dengan nomor: 81/KOMET/FK USU/2016 pada tanggal 26 Januari 2016.

Hasil pengukuran kekerasan permukaan enamel diolah secara statistik dengan menggunakan uji $\mathrm{T}$ Berpasangan dan One Way ANOVA yang dilanjutkan dengan uji Post Hoc.

\section{HASIL}

Digunakan uji $\mathrm{T}$ berpasangan untuk melihat makna perbedaan ekekrasan permukaan enamel setelah perendaman dalam obat kumur cengkeh dengan maupun tanpa penambahan saliva buatan.

Hasil uji $\mathrm{T}$ berpasangan pada kelompok obat kumur cengkeh memperlihatkan penurunan kekerasan permukaan enamel yang signifikan $(\mathrm{p}<0,05)$ pada semua kelompok waktu (Tabel 1).

Tabel 1. Hasil uji $\mathrm{T}$ berpasangan penurunan nilai kekerasan permukaan enamel dari perendaman jus jeruk kemasan dengan perendaman obat kumur cengkeh.

\begin{tabular}{|c|c|c|c|c|}
\hline \multirow[b]{2}{*}{ Kel } & \multicolumn{2}{|c|}{$\begin{array}{c}\text { Nilai kekerasan } \\
\text { permukaan enamel } \\
(\mathrm{VHN})\end{array}$} & \multirow{2}{*}{$\begin{array}{c}\text { Pe } \\
\text { nurunan } \\
\text { nilai VHN }\end{array}$} & \multirow[b]{2}{*}{ Sig. (p) } \\
\hline & $\begin{array}{l}\text { Setelah } \\
\text { perendam } \\
\text { an jus } \\
\text { jeruk }\end{array}$ & $\begin{array}{l}\text { Setelah } \\
\text { perendaman } \\
\text { obat kumur } \\
\text { cengkeh }\end{array}$ & & \\
\hline A1 & $\begin{array}{c}343,32 \pm 31 \\
, 24\end{array}$ & $\begin{array}{c}283,51 \pm 30 \\
, 65\end{array}$ & 59,81 & $0,000^{*}$ \\
\hline A2 & $\begin{array}{c}332,68 \pm 40 \\
, 41\end{array}$ & $\begin{array}{c}270,77 \pm 42 \\
, 48\end{array}$ & 61,92 & $0,000 *$ \\
\hline A3 & $\begin{array}{c}354,68 \pm 7 \\
12\end{array}$ & $\begin{array}{c}263,97 \pm 26 \\
, 10\end{array}$ & 65,71 & $0,008^{*}$ \\
\hline A4 & $\begin{array}{c}353,13 \pm 17 \\
, 68\end{array}$ & $\begin{array}{c}256,10 \pm 41 \\
, 00\end{array}$ & 97,03 & $0,015^{*}$ \\
\hline
\end{tabular}

*terdapat perbedaan signifikan pada $\mathrm{p}<0,05$

Hasil uji $\mathrm{T}$ berpasangan pada kelompok obat kumur cengkeh yang ditambah saliva buatan memperlihatkan peningkatan kekerasan permukaan enamel yang signifikan $(\mathrm{p}<0,05)$ pada semua kelompok waktu (Tabel 2). 
Tabel 2. Hasil uji $\mathrm{T}$ berpasangan peningkatan nilai kekerasan permukaan enamel dari perendaman jus jeruk kemasan dengan perendaman obat kumur cengkeh yang ditambah saliva buatan. Nilai kekerasan permukaan enamel

\begin{tabular}{|c|c|c|c|c|}
\hline \multirow[b]{2}{*}{ Kel } & \multicolumn{2}{|c|}{$(\mathrm{VHN})$} & \multirow{2}{*}{$\begin{array}{c}\text { Penin } \\
\text { gkatan } \\
\text { nilai } \\
\text { VHN }\end{array}$} & \multirow[b]{2}{*}{ Sig. (p) } \\
\hline & $\begin{array}{c}\text { Setelah } \\
\text { perenda } \\
\text { man jus } \\
\text { jeruk }\end{array}$ & $\begin{array}{c}\text { Setelah } \\
\text { perendaman } \\
\text { obat kumur } \\
\text { cengkeh }\end{array}$ & & \\
\hline B1 & $\begin{array}{c}343,53 \pm 9 \\
, 66\end{array}$ & $\begin{array}{c}400,07 \pm 3,0 \\
0\end{array}$ & 56,54 & $0,001 *$ \\
\hline B2 & $\begin{array}{c}333,42 \pm 1 \\
2,92\end{array}$ & $\begin{array}{c}385,26 \pm 7,5 \\
8\end{array}$ & 51,84 & $0,001 *$ \\
\hline B3 & $\begin{array}{c}351,55 \pm 3 \\
4,62\end{array}$ & $\begin{array}{c}401,20 \pm 25 \\
67\end{array}$ & 49,66 & $0,010^{*}$ \\
\hline B4 & $\begin{array}{c}347,77 \pm 2 \\
2,50\end{array}$ & $\begin{array}{c}398,24 \pm 13 \\
70\end{array}$ & 50,48 & $0,000^{*}$ \\
\hline
\end{tabular}

*terdapat perbedaan signifikan pada $\mathrm{p}<0,05$

Tabel 3 memperlihatkan perbandingan nilai rerata kekerasan permukaan enamel yang direndam dalam obat kumur cengkeh dengan penambahan saliva buatan maupun tanpa penambahan saliva buatan yang diuji dengan uji statistik One Way ANOVA. Dalam melakukan perbandingan antar kelompok, digunakan data selisih nilai rerata kekerasan permukaan enamel setelah perendaman obat kumur cengkeh dengan nilai setelah perendaman jus jeruk kemasan $(\Delta \mathrm{VHN})$. Hasil uji statistik One Way ANOVA yang membandingkan selisih nilai rerata kekerasan permukaan enamel setelah perendaman obat kumur cengkeh, dengan dan tanpa ditambah saliva buatan menunjukkan perbedaan yang signifikan $(\mathrm{p}<0,05)$ pada semua kelompok waktu.

Tabel 3. Hasil uji statistik One Way ANOVA perbedaan rerata kekerasan permukaan enamel setelah direndam dalam obat kumur cengkeh dengan penambahan saliva buatan maupun tanpa penambahan saliva buatan.

\begin{tabular}{lll}
\hline \multicolumn{1}{c}{ Kelompok } & $\Delta$ VHN & Sig. (p) \\
\hline $\begin{array}{l}\text { A1 (Obat kumur cengkeh 30 } \\
\text { detik) }\end{array}$ & $-59,81$ & \\
A2 ( Obat kumur cengkeh 1 & $-61,92$ & \\
menit) & & \\
A3 (Obat kumur cengkeh 2 & $-65,71$ & \\
menit) & & \\
A4 (Obat kumur cengkeh 4 & $-97,000^{*}$ \\
menit) & 56,54 & \\
\hline $\begin{array}{l}\text { B1 (Obat kumur cengkeh }+ \\
\text { saliva buatan 30 detik) }\end{array}$ & \\
$\begin{array}{l}\text { B2 ( Obat kumur cengkeh }+ \\
\text { saliva buatan 1 menit) }\end{array}$ & 51,84 & \\
$\begin{array}{l}\text { B3 (Obat kumur cengkeh }+ \\
\text { saliva buatan 2 menit) } \\
\text { B4 (Obat kumur cengkeh }+ \\
\text { saliva buatan 4 menit) }\end{array}$ & 49,66 & \\
\hline
\end{tabular}

*terdapat perbedaan signifikan pada $\mathrm{p}<0,05$
Hasil uji Post Hoc (Tabel 4) yang membandingkan selisih kekerasan permukaan enamel setelah perendaman obat kumur cengkeh dengan dan tanpa saliva buatan menunjukkan perbedaan yang signifikan $(\mathrm{p}<0,05)$ pada setiap kelompok waktu.

Tabel 4. Hasil uji statistik Post Hoc perbedaan rerata kekerasan permukaan enamel yang direndam dalam obat kumur cengkeh dengan penambahan saliva buatan maupun tanpa penambahan saliva buatan.

\begin{tabular}{|c|c|c|c|c|}
\hline $\begin{array}{c}\text { Kelompok } \\
\text { perendaman } \\
\text { obat kumur } \\
\text { cengkeh }\end{array}$ & Waktu & $\Delta \mathrm{VHN}$ & Mean & $\begin{array}{l}\text { Sig. } \\
\text { (p) }\end{array}$ \\
\hline $\begin{array}{c}\text { A1 (-) saliva } \\
\text { buatan } \\
\text { B1 (+) saliva } \\
\text { buatan }\end{array}$ & $\begin{array}{c}30 \\
\text { detik }\end{array}$ & $\begin{array}{l}-59,81 \\
56,54\end{array}$ & 116,34 & $0.000 *$ \\
\hline $\begin{array}{c}\text { A2 (-) saliva } \\
\text { buatan } \\
\text { B2 }(+) \text { saliva } \\
\text { buatan }\end{array}$ & $\begin{array}{c}1 \\
\text { menit }\end{array}$ & $\begin{array}{l}-61,92 \\
51,84\end{array}$ & 113,75 & $0.000 *$ \\
\hline $\begin{array}{c}\text { A3 (-) saliva } \\
\text { buatan } \\
\text { B3 (+) saliva } \\
\text { buatan }\end{array}$ & $\begin{array}{c}2 \\
\text { menit }\end{array}$ & $-65,71$ & 115,37 & $0.000^{*}$ \\
\hline $\begin{array}{c}\text { A4 (-) saliva } \\
\text { buatan } \\
\text { B4 (+) saliva } \\
\text { buatan }\end{array}$ & $\begin{array}{c}4 \\
\text { menit }\end{array}$ & $-97,03$ & 147,50 & $0.000^{*}$ \\
\hline
\end{tabular}

*terdapat perbedaan signifikan pada $\mathrm{p}<0,05$

\section{PEMBAHASAN}

Pada penelitian ini, seluruh sampel setelah direndam dengan jus jeruk kemasan mengalami penurunan kekerasan enamel, sedangkan keempat kelompok A1, A2, A3, dan A4 dimana gigi direndam obat kumur cengkeh setelah perendaman jus jeruk kemasan juga mengalami penurunan nilai rata-rata kekerasan permukaan enamel yang signifikan $(\mathrm{p}<0,05)$. Penurunan kekerasan enamel dapat terjadi karena gigi mengalami demineralisasi. Demineralisasi terjadi karena $\mathrm{pH}$ jus jeruk kemasan dan obat kumur cengkeh berada di bawah $\mathrm{pH}$ krtitis enamel gigi $(<5,5)$, dimana $\mathrm{pH}$ jus jeruk kemasan adalah 3,6 dan $\mathrm{pH}$ obat kumur cengkeh adalah 4,7 sehingga ketika jus jeruk kemasan dan obat kumur cengkeh berkontak dengan enamel menyebabkan ion $\mathrm{OH}^{-}$meningkat dan semakin tinggi pelepasan ion $\mathrm{Ca}^{2+}$ dan $\mathrm{PO}_{4}{ }^{3-}$ pada hidroksiapatit enamel gigi $\left(\mathrm{Ca}_{10}\left(\mathrm{PO}_{4}\right)_{6}(\mathrm{OH})_{2}\right.$ sehingga kekerasan enamel berkurang. ${ }^{4}$ Hasil penelitian yang didapat pada penelitian ini berbeda dengan yang dilaporkan oleh Al-lami AHK dan Al-lousi WS di Irak (2011), dimana penelitian yang mereka lakukan menunjukkan bahwa larutan ekstrak bunga cengkeh $1 \%, 5 \%$, dan $10 \%$ dapat meningkatkan kekerasan permukaan enamel pada gigi yang telah di demineralisasi secara signifikan dan peningkatan kekerasan tertinggi adalah pada konsentrasi 5\%. Perbedaan ini disebabkan karena secara teori, ekstrak bunga cengkeh dalam bentuk larutan dengan pelarutnya berupa aquadest 
masih membawa mineral (dalam hal ini kalsium dan fosfor) yang terdapat pada cengkeh sehingga remineralisasi dapat terjadi ${ }^{5}$ sedangkan pada penelitian ini ekstrak cengkeh yang digunakan dalam obat kumur adalah dalam bentuk minyak (minyak cengkeh yang mengandung eugenol). Secara teori, pembuatan minyak cengkeh menggunakan proses destilasi. Proses destilasi dalam pembuatan minyak cengkeh yang terkandung pada obat kumur ini menyebabkan eugenol pada cengkeh menguap dahulu (titik didih eugenol $253^{\circ} \mathrm{C}$ ) karena mempunyai titik didih yang lebih rendah dari kalsium $\left(1484^{\circ} \mathrm{C}\right)$ dan fosfor $\left(280^{\circ} \mathrm{C}\right)$ sedangkan kalsium dan fosfor tidak turut menguap karena mempunyai titik didih yang berbeda. ${ }^{9-11}$ Proses ini menyebabkan kandungan kalsium dan fosfor pada cengkeh sangat sedikit atau bahkan tidak terkandung pada minyak cengkeh. ${ }^{2,6}$ Oleh karena itu peneliti menyarankan penelitian lanjutan mengenai penggunaan ekstrak cengkeh dalam bentuk ekstrak lain selain dalam bentuk minyak esensial dalam obat kumur.

Kandungan eugenol pada ekstrak cengkeh yang terdapat pada obat kumur ini bersifat asam lemah yang berfungsi sebagai antibakteri, antimikroba, dan antifungal. ${ }^{2}$ Namun meskipun eugenol bersifat asam, eugenol dapat menghambat dekalsifikasi enamel. Hal ini dibuktikan dari penelitian Marya CM dkk di India (2012) yang menunjukkan bahwa minyak cengkeh $0,05 \%$ yang dicampurkan pada jus apel dengan $\mathrm{pH} 3,2$ dapat menghambat proses dekalsifikasi enamel oleh jus apel ${ }^{6}$ artinya dengan $\mathrm{pH}$ yang rendah (dibawah $\mathrm{pH}$ kritis enamel), dekalsifikasi enamel dapat dihambat sehingga penurunan kekerasan permukaan enamel dapat dihambat. Minyak cengkeh juga mengandung tannin yang dapat meningkatkan ketahanan terhadap asam pada enamel gigi ${ }^{5}$ sehingga kemungkinan penurunan kekerasan permukaan enamel yang terjadi bisa lebih tinggi tanpa adanya eugenol dan tannin yang terkandung dalam minyak cengkeh.

Hasil penelitian juga menunjukkan bahwa semakin lama perendaman dalam obat kumur cengkeh, maka semakin besar pula penurunan kekerasan permukaan enamel (Tabel 4). Hal ini sesuai dengan penelitian Arief EP di Indonesia (2007) yang menyatakan kontak yang lama antara enamel dan larutan asam di sekitarnya akan mengakibatkan demineralisasi terjadi terus menerus, menyebabkan kehilangan sebagian dari prisma enamel, sehingga kekerasan permukaan enamel gigi akan semakin berkurang ${ }^{3,14}$ sehingga peneliti berpendapat bahwa lebih baik berkumur selama 30 detik sesuai anjuran pabrik agar efek demineralisasi lebih lanjut dapat dihindari.

Penurunan nilai kekerasan permukaan enamel juga dapat disebabkan karena $\mathrm{pH}$ obat kumur cengkeh yang berada di bawah $\mathrm{pH}$ kritis enamel sehingga menyebabkan enamel mengalami demineralisasi. $\mathrm{pH}$ obat kumur cengkeh pada penelitian ini adalah 4,7. Diketahui bahwa makanan maupun minuman ringan, minuman olahraga, jus buah, serta minuman beralkohol dengan $\mathrm{pH}$ asam $(<5,5)$ dapat menimbulkan erosi dan penurunan kekerasan permukaan enamel. ${ }^{4,7,8}$ Namun pada umumnya obat kumur memang diproduksi dalam $\mathrm{pH}$ asam untuk memaksimalkan efek pengawet pada obat kumur. ${ }^{12}$
Pratama IJ dkk di Indonesia (2013) menyatakan bahwa semakin kecil konsentrasi ekstrak cengkeh, maka akan semakin basa sifat pHnya. ${ }^{3}$ Konsentrasi minyak cengkeh yang digunakan dalam obat kumur ini adalah $0,35 \%$, dimana konsentrasi ini lebih tinggi dibandingkan dengan konsentrasi minyak cengkeh yang digunakan oleh Marya CM dkk di India (2012) yaitu sebesar 0,05\%. Meskipun Marya CM dkk tidak menyebutkan $\mathrm{pH}$ minyak cengkeh yang dipakai dalam penelitiannya, namun kemungkinan $\mathrm{pH}$ minyak cengkeh yang digunakan dalam obat kumur ini lebih asam dibandingkan dengan $\mathrm{pH}$ minyak cengkeh yang digunakan oleh Marya CM dkk karena konsentrasi minyak cengkeh pada obat kumur ini lebih tinggi dibandingkan penelitian tersebut. Dengan adanya kandungan sodium benzoate sebagai pengawet dalam obat kumur cengkeh ini juga dapat menjadi salah satu alasan obat kumur cengkeh ini dibuat dengan $\mathrm{pH}$ rendah. Sodium benzoate berfungsi sebagai antibakteri dan pengawet. Diketahui sodium benzoate mempunyai efek pengawet yang maksimal seiring dengan menurunnya $\mathrm{pH}$ suatu larutan ${ }^{13}$ sehingga kemungkinan pabrik mengatur $\mathrm{pH}$ obat kumur cengkeh ini menjadi asam agar efek sodium benzoate sebagai pengawet dapat bekerja maksimal. Komposisi lain selain minyak cengkeh dan sodium benzoate yang terkandung dalam obat kumur cengkeh dalam penelitian ini diperuntukkan untuk antibakteri dan antimikroba ${ }^{15-17}$ sehingga peneliti berasumsi bahwa obat kumur cengkeh ini dimaksimalkan untuk antibakteri saja namun tidak sebagai agen remineralisasi.

Saliva dapat membantu proses remineralisasi enamel oleh karena adanya komposisi saliva seperti ion kalsium, fosfat, bikarbonat, urea, dan sialin. Aliran saliva dapat mengurangi kontak langsung asam dengan enamel, juga dapat menetralkan kembali $\mathrm{pH}$ rongga mulut sehingga remineralisasi dapat terjadi. ${ }^{17} \mathrm{Hal}$ ini terbukti dari hasil penelitian pada Tabel 3 yang menunjukkan dengan penambahan saliva buatan pada obat kumur cengkeh pada kelompok B1, B2, B3, dan B4 dapat meningkatkan nilai rata-rata kekerasan permukaan enamel yang signifikan $(\mathrm{p}<0,05)$. Peningkatan yang terjadi bahkan melebihi nilai kekerasan awal (Tabel 1). Hal ini terjadi karena selain sebagai buffer yang dapat menetralkan asam, difusi komponen anorganik dan organik pada saliva pada enamel dapat menurunkan kelarutan enamel dan meningkatkan remineralisasi gigi sehingga terjadi peningkatan kekerasan permukaan enamel. $^{17}$

Oleh karena itu, dari penelitian ini peneliti berpendapat bahwa obat kumur yang mengandung minyak cengkeh ini baik dan aman untuk digunakan karena pada kenyataannya terdapat saliva pada rongga mulut yang dapat memicu remineralisasi pada rongga mulut. Hal ini tampak dari dengan penambahan saliva buatan pada obat kumur cengkeh dapat meningkatkan kekerasan permukaan enamel. Selain itu, pada individu yang mempunyai kelainan kelenjar saliva seperti xerostomia, obat kumur cengkeh ini pun baik untuk digunakan namun dengan penambahan saliva buatan pada individu tersebut.

Kesimpulan dari penelitian ini adalah lebih tinggi nilai kekerasan permukaan enamel pada perendaman obat 
kumur cengkeh dengan tambahan saliva buatan dibandingkan tanpa penambahan saliva buatan.

\section{DAFTAR PUSTAKA}

1. Anggayanti NA, Adiatmika IPG, Adiputra N. Berkumur dengan teh hitam lebih efektif daripada chlorhexidine gluconate $0,2 \%$ untuk menurunkan akumulasi plak gigi. Jurnal PDGI 2013; 62(2): 35-40.

2. Bhowmik D, Kumar KPS, Yadav A, Srivastava S, Paswan S, Dutta AS. Recent trends in indian traditional herbs syzygium aromaticum and its health benefits. $\mathbf{J}$ of Pharmacognosy and Phytochemistry 2012; 1(1): 14-21.

3. Pratama IKJ, Adi P, Prasetyaningrum N. Pengaruh larutan ekstrak bunga cengkeh (syzygium aromaticum) terhadap perubahan ph saliva buatan yang diinduksi streptococcus mutans secara in vitro. Jurnal PDGI 2013; 62(2): 35-40.

4. Lussi A, Jaeggi T. Erosion-diagnosis and risk factors. Clin Oral Invest 2008; 12(1): 7-9.

5. Al-lami AHK, Al-Alousi WS. Effect of water clove extract on the microhardness and microscopic features of initial caries-like lesion of permanent teeth, compared to fluoridated agent. J Bagh College Dentistry 2011; 23(2): 1-4.

6. Marya CM, Satija G, Avinash J, Nagpal R, Kapoor R, Ahmad A. In vitro inhibitory effect of clove essential oil and its two active principles on tooth decalcification by apple juice. Int $\mathrm{J}$ Dent 2012: 1-6.

7. Tahmassebi JF, Duggal MS, Kotru GM, Curzon MEJ. Soft drinks and dental health: a review of the current literature. J Dent 2006; 34: 2-6.

8. Machado C, Lacefield W, Catledge A. Human enamel microhardness, elastic modulus and surface integrity after beverage contact. BrazDent J 2008; 19(1): 68-72.

9. Aziz T, Yuanita, Susanti. Ekstraksi eugenol dari daun salam india. Jurnal Teknik Kimia 2010; 3(17): 19-21.

10. Tatang. Kegunaan unsur kalsium dan sejarah kalsium. smpsma.com/kegunaan-unsur-kalsiumdan-sejarah-kalsium.html (19 Maret 2016)

11. Hikmat. Pengertian unsur fosfor dan efeknya. http://kliksma.com/2015/04/pengertian-unsurfosfor-dan-efeknya.html (19 Maret 2016)

12. Frey S. What can change the ph of someone's mouth. https://www.quora.com/What-canchange-the-pH-of-someones-mouth (30 Maret 2016)

13. Lalitha C, Rao PVVP. Antimicrobial efficacy of low level cosmetic preservatives. World J Pharmacy and Pharmaceutical Sci 2014; 3(2): 1688.

14. Arief EP, Kunarti S. The effect of acidulated phosphate fluoride application on dental enamel surface hardness. Dent J (Maj Ked Gigi) 2007; 40(3): 145-7.

15. Subramaniam P, Nandan N. Effect of xylitol, sodium fluoride and triclosan containing mouth rinse on streptococcus mutans. Contemp Clin Dent 2011; 2(4): 287-90.

16. Al-Sum BA, Al-Arfaj AA. Antimicrobial activity of the aqueous extract of mint plant. Sci J Clin Med 2013; 2(3): 110-3.

17. Sujana P, Sridhar Tm. Jothna P. Naidu CV. Antibacterial activity and phytochemical analysis of mentha piperita $L$. (peppermint)- an important multipurpose medicinal plant. American J Plant Sci 2013; 4: 78-82.

18. Almeida PDV, Gragio AMT, Machado MAN, Lima AAS, Azevedo LR. Saliva composition and functions: a comprehensive review. J Contemp Dent Pract 2008; 9(3): 2. 